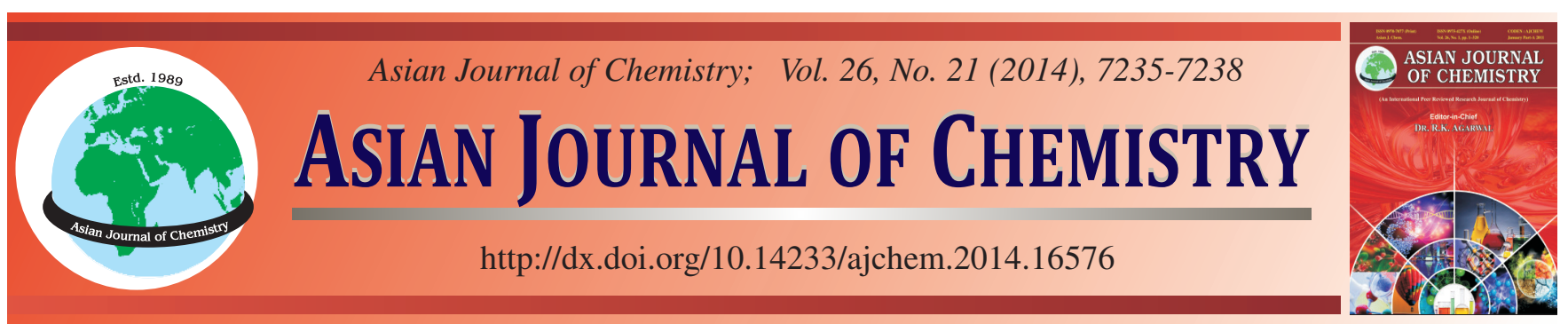

\title{
Synthesis, Characterization and Preliminary in vitro Antibacterial Screening Activity of Organotin(IV) Complexes Derivatives of 2-Amino-3-nitrobenzoic Acid
}

\author{
Chen-Shang Choong, Sie-Tiong Ha, Mei-Hsuan Heng and Yip-Foo Win*
}

Faculty of Science, Universiti Tunku Abdul Rahman, Perak Campus, Jalan Universiti, Bandar Barat, 31900 Kampar, Perak, Malaysia

*Corresponding author: Fax: +60 5 4661676; Tel: +60 5 4688888; E-mail: williamyfw@yahoo.com

\begin{abstract}
A total of four organotin(IV) carboxylate complexes have been synthesized and characterized quantitatively and qualitatively. Spectroscopy studies indicated that the coordination took place via oxygen atoms from the carboxylate anions. Moreover, all the complexes obtained as simple monomeric structure except complex $\mathbf{3}$ which was obtained as organodistannoxane dimer types. From the preliminary in vitro antibacterial screening activity, triphenyltin(IV) (complex 4) showed significant activity against Bacillus subtilis, Pseudomonas aeruginosa and Staphylococcus aureus and complex 2 only possessed better activity against Pseudomonas aeruginosa.
\end{abstract}

Keywords: Organotin(IV) carboxylate, 2-Amino-3-nitrobenzoic acid.

\section{INTRODUCTION}

The coordination chemistry of organotin(IV) complexes are extensively studied due to its structural diversity from a simple monomer until polymeric structures ${ }^{1-8}$. In addition, in some studies showed that the overall structure of organotin(IV) complexes including its 3D crystal structure packing also influenced by the participation of coordinating solvent molecules such as water, acetone, methanol and ethanol to tin(IV) atoms moieties ${ }^{5-8}$. The biological properties of organotin(IV) complexes also have been extensively studied in order to explore its structural-activity relationship ${ }^{9-13}$.

In this paper, we report the synthesis, characterization and preliminary in vitro antibacterial screening activity of organotin(IV) complexes derivatives of 2-amino-3-nitrobenzoic acid.

\section{EXPERIMENTAL}

All the reagents, starting materials as well as the solvents were purchased commercially and used without any further purification. The melting points were determined in an open capillary and were uncorrected. Elemental C, $\mathrm{H}$ and $\mathrm{N}$ analyses were carried out on a Perkin-Elmer $2400 \mathrm{CHN}$ elemental analyzer. The infrared spectra were recorded using a PerkinElmer System 2000 FTIR Spectrophotometer as a $\mathrm{KBr}$ disc in the frequency range of $4000-400 \mathrm{~cm}^{-1}$. The spectra for ${ }^{1} \mathrm{H},{ }^{13} \mathrm{C}$, ${ }^{1} \mathrm{H}-{ }^{13} \mathrm{C}$ HMQC and ${ }^{119} \mathrm{Sn}$ NMR were recorded on a JEOL JNMECX 400 FT-NMR Spectrometer using deuterated $\mathrm{CDCl}_{3}$ and DMSO- $d_{6}$ as the solvent and tetramethylsilane, TMS as the internal standard.
The preliminary in vitro antibacterial screening activity was carried out against two Gram-negative [Escherichia coli (ATCC 25922) and Pseudomonas aeruginosa (ATCC 27853)] and two Gram-positive [Bacillus subtilis (ATCC 38583) and Staphylococcus aureus (ATCC 25923)] bacterial strains by inhibition zone method using paper disc diffusion method ${ }^{14}$. The seeded agar (nutrient agar medium) was prepared by cooling the molten agar to $40^{\circ} \mathrm{C}$ and then adding bacterial inoculums containing approximately $1 \times 10^{4}-10^{8}$ colony forming units $(\mathrm{CFU}) / \mathrm{mL}$. The bacterial inoculums were spread on the plate containing agar medium and even coverage was ensured before the agar solidified. The complexes were dissolved in DMSO to prepare $1 \mathrm{mg} / \mathrm{mL}$ concentration. Later, small filter paper discs (6 mm) containing $1 \mathrm{mg} / \mathrm{mL}$ of the samples were laid on the growth medium. The plates were incubated immediately at $37{ }^{\circ} \mathrm{C}$ for $20-24 \mathrm{~h}$. The activity was determined by measuring the diameter of the inhibition zone (in $\mathrm{mm}$ ).

2-Amino-3-nitrobenzoic acid (HL): The parent acid, 2amino-3-nitrobenzoic acid (HL) was purchased from Aldrich Chemical Company (USA) and used without any further purification. In the early stage of synthesis, the attempt to prepare organotin(IV) complexes with dimethyltin(IV) oxide in methanol was unsuccessful. The resulting orange solution was filtered and orange crystals were collected. Unfortunately, the crystals obtained were found to be the starting material (acid itself) with the melting point of $209^{\circ} \mathrm{C}$ and the crystal structure of the acid has been report ${ }^{15}$. FTIR as $\mathrm{KBr}$ disc $\left(\mathrm{cm}^{-1}\right)$ : Selected data: $v(\mathrm{OH}) 2868-2561, v(\mathrm{COO})_{\text {as }} 1668, v(\mathrm{COO}) \mathrm{s} 1251, \Delta v$ $=417 .{ }^{1} \mathrm{H}$ NMR $(\mathrm{ppm})\left(\mathrm{DMSO}-d_{6}\right): \delta$ benzene protons $6.68(\mathrm{t}$, 
$7.4 \mathrm{~Hz}, 1 \mathrm{H}) ; 8.18$ (d, $7.3 \mathrm{~Hz}, 1 \mathrm{H}) ; 8.26$ (d, $7.8 \mathrm{~Hz}, 1 \mathrm{H}) .{ }^{13} \mathrm{C}$ NMR (ppm) (DMSO- $\left.d_{6}\right): \delta$ benzene carbons $113.98,114.79$, 131.77, 132.53, 139.81, 146.86; COO 168.86.

Preparation of dimethyltin(IV) oxide, $\mathrm{Me}_{2} \mathrm{SnO}$ and sodium salt: Dimethyltin(IV) dichloride was dissolved in distilled water and stirred for $16 \mathrm{~h}$. Colourless solution was obtained. Ammonia solution (60\%) was added into the colourless solution and finally white precipitate was obtained. The precipitate was placed in an oven $\left(60^{\circ} \mathrm{C}\right)$ for a few days to dry. The sodium salt was obtained by heating under reflux a 1:1 molar mixture of sodium hydroxide, $\mathrm{NaOH}$ and 2-amino-3-nitrobenzoic acid in ethanol $(50 \mathrm{~mL})$ for two hours. After a few days, yellow precipitates were obtained. Sodium salt of 2-amino3-nitrobenzoic acid: FTIR as $\mathrm{KBr}$ disc $\left(\mathrm{cm}^{-1}\right)$ selected data: $\mathrm{v}(\mathrm{COO})_{\mathrm{as}} 1601, \mathrm{v}(\mathrm{COO})_{\mathrm{s}} 1263, \Delta \mathrm{v}=338$.

Preparation of (2- $\left.\mathrm{NH}_{2}-3-\mathrm{NO}_{2}-\mathrm{C}_{6} \mathrm{H}_{3} \mathrm{COO}\right)_{2}\left(\mathrm{CH}_{3}\right)_{2} \mathrm{Sn}$ (1): Complex 1 was obtained by heating under reflux a 1:2 molar mixture of dimethyltin(IV) oxide $(0.33 \mathrm{~g}, 2 \mathrm{mmol})$ and 2-amino-3-nitrobenzoic acid $(0.73 \mathrm{~g}, 4 \mathrm{mmol})$ in ethanol (50 $\mathrm{mL}$ ) for $2 \mathrm{~h}$. A yellow transparent solution was separated by filtration and kept in a bottle. After few days, yellow precipitates (0.78 g, $76.5 \%$ yield) were collected. m.p.: 196-198 ${ }^{\circ} \mathrm{C}$. Analysis for $\mathrm{C}_{16} \mathrm{H}_{16} \mathrm{~N}_{4} \mathrm{O}_{8} \mathrm{Sn}$ : C, 36.98; H, 3.08; N, $10.06 \%$. Calculated for $\mathrm{C}_{16} \mathrm{H}_{16} \mathrm{~N}_{4} \mathrm{O}_{8} \mathrm{Sn}_{1}$ : C, 37.61; H, 3.16; N, $10.97 \%$. FTIR as $\mathrm{KBr} \operatorname{disc}\left(\mathrm{cm}^{-1}\right): \mathrm{v}(\mathrm{COO})_{\mathrm{as}} 1686 ; \mathrm{v}(\mathrm{COO})_{\mathrm{s}} 1252, \Delta v$ $=434 ; \mathrm{v}(\mathrm{O}-\mathrm{Sn}-\mathrm{O}) 601, \mathrm{v}(\mathrm{Sn}-\mathrm{C}) 538, \mathrm{v}(\mathrm{Sn}-\mathrm{O})$ 491. ${ }^{1} \mathrm{H}$ NMR (ppm) $\left(\mathrm{CDCl}_{3}\right): \delta$ benzene protons $6.71(\mathrm{t}, 8.2 \mathrm{~Hz}, 2 \mathrm{H}) ; 8.35$ (dd, $1.4 \mathrm{~Hz}, 7.8 \mathrm{~Hz}, 2 \mathrm{H}) ; 8.43(\mathrm{dd}, 1.4 \mathrm{~Hz}, 8.2 \mathrm{~Hz}, 2 \mathrm{H})$; methyl 1.19 (s, 6H). ${ }^{13} \mathrm{C}$ NMR (ppm) $\left(\mathrm{CDCl}_{3}\right): \delta$ benzene carbons 113.51, 114.21, 133.22, 133.38, 140.69, 147.60; methyl 5.10, COO 172.32. ${ }^{119} \mathrm{Sn}-\mathrm{NMR}(\mathrm{ppm})\left(\mathrm{CDCl}_{3}\right): \delta=-103.44$.

Preparation of (2- $\left.\mathrm{NH}_{2}-3-\mathrm{NO}_{2}-\mathrm{C}_{6} \mathrm{H}_{3} \mathrm{COO}\right)_{2}\left(\mathrm{C}_{4} \mathrm{H}_{9}\right)_{2} \mathrm{Sn}$ (2): Complex 2 was obtained by heating under reflux a 1:2 molar mixture of dibutyltin(IV) oxide $(0.50 \mathrm{~g}, 2 \mathrm{mmol})$ and 2-amino-3-nitrobenzoic acid $(0.73 \mathrm{~g}, 4 \mathrm{mmol})$ in ethanol (50 $\mathrm{mL}$ ) for $4 \mathrm{~h}$. A clear yellow transparent solution was separated by filtration and kept in a bottle. After few days, yellow precipitates (0.86 g, $67.8 \%$ yield) were collected. m.p.: 189-190 ${ }^{\circ} \mathrm{C}$. Analysis for $\mathrm{C}_{22} \mathrm{H}_{28} \mathrm{~N}_{4} \mathrm{O}_{8} \mathrm{Sn}: \mathrm{C}, 43.77 ; \mathrm{H}, 5.17 ; \mathrm{N}, 8.21 \%$. Calculated for $\mathrm{C}_{22} \mathrm{H}_{28} \mathrm{~N}_{4} \mathrm{O}_{8} \mathrm{Sn}: \mathrm{C}, 44.40 ; \mathrm{H}, 4.74 ; \mathrm{N}, 9.41 \%$. FTIR as $\mathrm{KBr} \operatorname{disc}\left(\mathrm{cm}^{-1}\right): \mathrm{v}(\mathrm{COO})_{\text {as }} 1631, \mathrm{v}(\mathrm{COO})_{\mathrm{s}} 1247, \Delta \mathrm{v}$ $=371$; v $(\mathrm{O}-\mathrm{Sn}-\mathrm{O})$ 622, v $(\mathrm{Sn}-\mathrm{C})$ 536, $\mathrm{v}(\mathrm{Sn}-\mathrm{O})$ 445. ${ }^{1} \mathrm{H}$ NMR $(\mathrm{ppm})\left(\mathrm{DMSO}-d_{6}\right): \delta$ benzene protons $6.69(\mathrm{t}, 7.8 \mathrm{~Hz}, 2 \mathrm{H})$; $8.22(\mathrm{~d}, 4.6 \mathrm{~Hz}, 2 \mathrm{H}) ; 8.25$ (d, $4.6 \mathrm{~Hz}, 2 \mathrm{H})$; butyl, $\mathrm{CH}_{3} 0.79$ (t, $7.3 \mathrm{~Hz}, 6 \mathrm{H}$ ); $\mathrm{CH}_{2} 1.27$ (sx, 7.3 Hz, 4H); $\mathrm{CH}_{2}$ 1.52-1.64 (m, $8 \mathrm{H}) .{ }^{13} \mathrm{C}$ NMR $(\mathrm{ppm})$ (DMSO- $\left.d_{6}\right): \delta$ benzene carbons 113.87 , 117.54, 130.88, 132.40, 140.04, 146.69; butyl 13.58, 25.64, 26.89, 30.38; COO 172.46. ${ }^{119} \mathrm{Sn}-\mathrm{NMR}$ (ppm) (DMSO- $d_{6}$ ): $\delta$ $=-317.60$.

Preparation of $\left[\left\{2-\mathrm{NH}_{2}-3-\mathrm{NO}_{2}-\mathrm{C}_{6} \mathrm{H}_{3} \mathrm{COO}\left(\mathrm{C}_{4} \mathrm{H}_{9}\right)_{2} \mathrm{Sn}\right\}_{2} \mathrm{O}\right]_{2}$ (3): Complex 3 was obtained by heating under reflux a 1:1 molar mixture of dibutyltin(IV) oxide $(0.50 \mathrm{~g}, 2 \mathrm{mmol})$ and 2-amino-3-nitrobenzoic acid $(0.36 \mathrm{~g}, 2 \mathrm{mmol})$. The reaction was carried out in a mixture of ethanol $(60 \mathrm{~mL})$ for $3 \mathrm{~h}$. A clear yellow solution was isolated by filtration and kept in a bottle. After few days, yellow crystals $(0.73 \mathrm{~g}, 83.7 \%$ yield $)$ were collected. m.p.: $140-142{ }^{\circ} \mathrm{C}$. Analysis for $\mathrm{C}_{60} \mathrm{H}_{92} \mathrm{~N}_{8} \mathrm{O}_{18} \mathrm{Sn}_{4}$ : C, 41.23; H, 6.62; N, $4.26 \%$. Calculated for $\mathrm{C}_{60} \mathrm{H}_{92} \mathrm{~N}_{8} \mathrm{O}_{18} \mathrm{Sn}_{4}$ : C, 42.69; H, 5.49; N, $6.64 \%$. FTIR as $\mathrm{KBr} \operatorname{disc}\left(\mathrm{cm}^{-1}\right)$ :
$v(\mathrm{COO})_{\text {as }} 1654,1632, v(\mathrm{COO})_{\mathrm{s}} 1247,1309, \Delta v=407,323$; $v(\mathrm{Sn}-\mathrm{O}-\mathrm{Sn}) 629, \mathrm{v}(\mathrm{Sn}-\mathrm{C}) 577, \mathrm{v}(\mathrm{Sn}-\mathrm{O}) 490 .{ }^{1} \mathrm{H}$ NMR $(\mathrm{ppm})$ $\left(\mathrm{CDCl}_{3}\right)$ : $\delta$ benzene protons $6.56(\mathrm{~s}, 4 \mathrm{H}) ; 8.14(\mathrm{~s}, 4 \mathrm{H}) ; 8.29$ (d, 7.8 Hz, 4H); butyl, $\mathrm{CH}_{3}$ 0.88-0.98 (m, 24H); $\mathrm{CH}_{2} 1.20-$ $1.54(\mathrm{~m}, 16 \mathrm{H}) ; \mathrm{CH}_{2} 1.59-1.73(\mathrm{~m}, 32 \mathrm{H}) .{ }^{13} \mathrm{C} \mathrm{NMR}(\mathrm{ppm})$ $\left(\mathrm{CDCl}_{3}\right): \delta$ benzene carbons $113.23,119.16,130.67,132.87$, 139.47, 147.74; butyl 13.68, 23.70, 25.84, 26.87, 27.08, 27.44, 27.61; COO 172.40. ${ }^{119} \mathrm{Sn}-\mathrm{NMR}(\mathrm{ppm})\left(\mathrm{CDCl}_{3}\right): \delta=-173.34$, -211.45 .

Preparation of 2- $\mathrm{NH}_{2}-3-\mathrm{NO}_{2}-\mathrm{C}_{6} \mathrm{H}_{3} \mathrm{COO}\left(\mathrm{C}_{6} \mathrm{H}_{5}\right)_{3} \mathrm{Sn}$ (4): The complex 4 was obtained by heating under reflux a 1:1 molar mixture of triphenyltin(IV) hydroxide ( $0.73 \mathrm{~g}, 2 \mathrm{mmol})$ and 2-amino-3-nitrobenzoic acid ( $0.36 \mathrm{~g}, 2 \mathrm{mmol})$ in methanol $(60 \mathrm{~mL})$ for $2 \mathrm{~h}$. A clear yellow transparent solution was isolated by filtration and kept in a bottle. After few days, yellow crystals $(0.46 \mathrm{~g}, 86 \%$ yield $)$ were collected. m.p: $155-156{ }^{\circ} \mathrm{C}$. Analysis for $\mathrm{C}_{25} \mathrm{H}_{20} \mathrm{~N}_{2} \mathrm{O}_{4} \mathrm{Sn}$ : C, 56.72; H, 3.73; N, $5.24 \%$. Calculated for $\mathrm{C}_{25} \mathrm{H}_{20} \mathrm{~N}_{2} \mathrm{O}_{4} \mathrm{Sn}: \mathrm{C}, 56.53 ; \mathrm{H}, 3.80 ; \mathrm{N}, 5.27 \%$. FTIR as $\mathrm{KBr} \operatorname{disc}\left(\mathrm{cm}^{-1}\right): \mathrm{v}(\mathrm{COO})_{\text {as }} 1635, \mathrm{v}(\mathrm{COO})_{\mathrm{s}} 1248, \Delta v$ $=387 ; \mathrm{v}(\mathrm{Sn}-\mathrm{O}) 446 .{ }^{1} \mathrm{H}$ NMR $(\mathrm{ppm})\left(\mathrm{DMSO}-d_{6}\right): \delta$ phenyl protons 7.41-7.48 (m, 9H); 7.76-7.94 (m, 6H); benzene 6.61 (t, $8.3 \mathrm{~Hz}, 1 \mathrm{H}) ; 8.15$ (dd, $1.8 \mathrm{~Hz}, 8.7 \mathrm{~Hz}, 1 \mathrm{H}) ; 8.19$ (dd, 1.8 $\mathrm{Hz}, 7.8 \mathrm{~Hz}, 1 \mathrm{H}) .{ }^{13} \mathrm{C}$ NMR (ppm) (DMSO- $d_{6}$ ): $\delta$ phenyl carbons $\mathrm{C}_{\text {ipso }} 142.97, \mathrm{C}_{\text {ortho }} 136.18(45.8 \mathrm{~Hz}), \mathrm{C}_{\text {meta }} 128.51(69.6 \mathrm{~Hz})$, $\mathrm{C}_{\text {para }}$ 129.07; benzene 113.70, 119.09, 130.12, 132.13, 139.80, 146.83; COO 169.99. ${ }^{119} \mathrm{Sn}-\mathrm{NMR}$ (ppm) (DMSO-d $): \delta=$ -263.25 .

\section{RESULTS AND DISCUSSION}

In this study, all the four complexes (1-4) have been successfully obtained in solid state. Only complex 4 was obtained as crystal form and the crystal structure has been reported ${ }^{16}$. The micro-elemental analysis for $\mathrm{C}, \mathrm{H}$ and $\mathrm{N}$ data obtained were in agreement with the predicted formula for complexes 1-4 together with the respective sharp melting points indicating the isolation of fairly pure complexes. An outline of the proposed structure for complexes 1-4 were depicted in Fig. 1.

The $v(\mathrm{O}-\mathrm{H})$ bands of the acid, HL was absent in the infrared spectra of salt and complexes 1-4 showed that the deprotonation and coordination of the carboxylate anion. In addition, complexes 2-4 revealed that the $\mathrm{v}(\mathrm{COO})_{\text {as }}$ was shifted to a lower wavelength number compared to the acid, HL which signified that the coordination took place via the oxygen atoms of the carboxylate anion. The magnitude of $\Delta v=\left[\mathrm{v}(\mathrm{COO})_{\mathrm{as}}\right.$ $\left.v(\mathrm{COO})_{\mathrm{s}}\right]$ is an useful indicator in the correlation of the coordination modes of the carboxylate anion to the tin(IV) atom in the organotin(IV) carboxylate complexes ${ }^{17}$. In general, if the $\Delta v$ value of complexes is greater by $65-90 \mathrm{~cm}^{-1}$ compared to their sodium salts indicating either asymmetric or monodentate bonding of the carboxylate anions and if the $\Delta v$ values being comparable or slightly higher by at most $50 \mathrm{~cm}^{-1}$ than those of the sodium salts, the carboxylate anions chelate bidentately to the tin(IV) atom ${ }^{17}$. Based on the comparison of $\Delta v$ values of complexes 1-4 and sodium salt, the carboxylate anion were bonded to tin(IV) atom in monodentate manner in complex 1; bidentate manner in complex 2; and exhibited monodentate and bidentate bonding manner in complex $\mathbf{3}$. For complexes derivatives of triphenyltin(IV) carboxylate, $\Delta v$ greater than $200 \mathrm{~cm}^{-1}$ would be expected for the monodentate 
<smiles>C[R16](C)(C)OC(OC(=O)c1cccc([N+](=O)[O-])c1N)OC(=O)c1cccc([N+](=O)[O-])c1N</smiles>

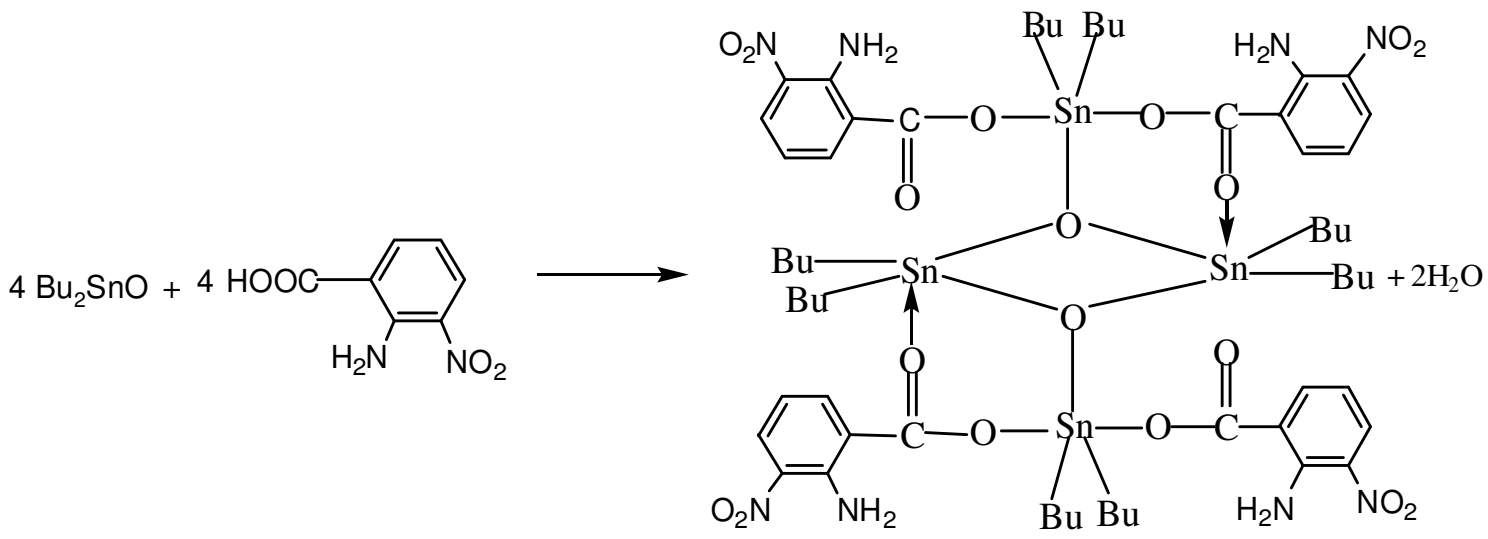

3<smiles>CC(C)CC(=O)OC[Sn](c1ccccc1)(c1ccccc1)c1ccccc1</smiles>

$\mathrm{Me}=$ methyl, $\mathrm{Bu}=$ butyl $\& \mathrm{Ph}=$ phenyl

Fig. 1. Proposed structure of complexes 1-4

bonding carboxylate anions ${ }^{18}$. Hence, the carboxylate anion in complex 4 would be expected to bond to the tin(IV) atom in monodentate manner since the $\Delta v$ above $200 \mathrm{~cm}^{-1}$. For further evidence of the coordination of carboxylate anion, this can be revealed by the presence of $v(\mathrm{O}-\mathrm{Sn}-\mathrm{O}) / \mathrm{v}(\mathrm{Sn}-\mathrm{O}-\mathrm{Sn})$ and $v(\mathrm{Sn}-\mathrm{O})$ stretching bands in the wavelength number at 629601 and 491-445 $\mathrm{cm}^{-1}$ in the spectra of complexes 1-4.

The ${ }^{1} \mathrm{H}$ NMR spectra of complexes 1-4 exhibited similarities to the acid, HL. The only exceptional and predictable observation were the occurrence of the methyl and butyl protons signals of complexes 1-3 at $1.19 \mathrm{ppm}$ and in the range of 0.79-1.73 ppm, respectively. The appearance of two well separated sets of multiplets in the regions centering around $\delta$ $\approx 7.45$ and $7.85 \mathrm{ppm}$ (downfield) ascribed to the phenyl protons of complex $\mathbf{4}^{19}$.

The ${ }^{13} \mathrm{C}$ NMR spectra of complexes 1-4 showed that the $\delta(\mathrm{COO})$ signals shifted to the downfield region which was lower compared to that of the acid, HL indicating the carboxylate anions were bonded to tin(IV) atoms. Complex 1 exhibited a sharp signal at $5.10 \mathrm{ppm}$ indicating the presence of the methyl groups in the $\mathrm{SnMe}_{2}$ moiety whereas complex 2 exhibited four sharp signals at 13.58, 25.64, 26.89 and 30.38 ppm indicating the presence of the butyl groups of the $\mathrm{SnBu}_{2}$ moiety. Moreover, complex $\mathbf{3}$ was derivatives of organodistannoxane dimer types exhibited two sets of signals corresponding to the butyl groups linked to the exo- and endo-cyclic tin(IV) atoms, respectively ${ }^{20}$. Complex $\mathbf{4}$ revealed the chemical shift of the $\delta\left({ }^{13} \mathrm{C}\right)_{\text {ipso }}$ at $142.97 \mathrm{ppm}$ indicative of a five-coordinated $\operatorname{tin}(\mathrm{IV})$ atom $^{21}$. Thus, indicating that the tin(IV) atom in complex $\mathbf{4}$ was five-coordinated and has a trigonal bipyramid geometry ${ }^{21}$.

The $\delta\left({ }^{119} \mathrm{Sn}\right)$ values of the five-coordinated diorganotin(IV) complexes fall in the range between -90 to $-190 \mathrm{ppm}$ and the six-coordinated complexes between -210 to $-400 \mathrm{ppm}^{22}$. The $\delta\left({ }^{19} \mathrm{Sn}\right)$ values of complexes $\mathbf{1}$ and $\mathbf{2}$ were -103.44 and -317.60 $\mathrm{ppm}$, respectively indicating that the tin(IV) atom in complex $\mathbf{1}$ was five-coordinated whereas the tin(IV) atom in complex $\mathbf{2}$ was six-coordinated. Complex $\mathbf{3}$ exhibited two well resolved $\delta\left({ }^{119} \mathrm{Sn}\right)$ signals at -173.34 and $-211.45 \mathrm{ppm}$ indicating two tin(IV) atoms were five-coordinated and another two tin(IV) atoms were six-coordinated. In general, the $\delta\left({ }^{119} \mathrm{Sn}\right)$ value of triphenyltin(IV) complexes lie in the range between - 180 to $-260 \mathrm{ppm}$ was believed to be five-coordinated and in the distorted trigonal bipyramid geometry. Complex $\mathbf{4}$ showed that 
the $\delta\left({ }^{119} \mathrm{Sn}\right)$ value at $-263.25 \mathrm{ppm}$ indicated the tin(IV) atom was five-coordinated and possessed a trigonal bipyramid geometry ${ }^{21}$. From the ${ }^{119} \mathrm{Sn}$ NMR study, it is strongly to conclude that the all the carboxylate anions were bonded to the tin(IV) atoms in bidentate manner. This phenomenon may due to upon in solution form, the organic groups of complexes 1-4 were undergo self-arrangement and in the dynamic state resulting the carboxylate anions were closer to the tin(IV) atoms moieties to exhibit dative bonding.

The preliminary in vitro antibacterial screening activity of acid, HL and complexes 1-4 were given in Table-1. Inhibition zones with a diameter less than $10 \mathrm{~mm}$ are considered as weak; larger than $10 \mathrm{~mm}$ but less than $16 \mathrm{~mm}$ are considered as moderate and finally larger than $16 \mathrm{~mm}$ and above are active. Based on the study, acid, HL was found to be inactive and complex 1 showed a weak activity to all the tested bacterial strains. In addition, complex $\mathbf{4}$ was found to show selective activity against Bacillus subtillis, Pseudomonas aeruginosa and Staphylococcus aureus at $1 \mathrm{mg} / \mathrm{mL}$ with the inhibition zones of 20, 19 and $20 \mathrm{~mm}$, respectively indicating the activities were in the active mode. Among the dibutyltin(IV) complexes, complex 2 only showed significant activity against Pseudomonas aeruginosa with the inhibition zone of $22 \mathrm{~mm}$. Overall, in this study the triphenyltin(IV) complexes is pronounced to be more active against three bacterial strains compared to diorganotin(IV) complexes and this was due to complex $\mathbf{4}$ was derivatives of triorganotin(IV) which is known to possess higher biological activity compared to diorgano$\operatorname{tin}(\mathrm{IV})^{20}$. Although complex 4 showed significant in vitro antibacterial activity against Gram-positive bacterial strains but the value obtained were lower compared to the reference drugs.

\begin{tabular}{|c|c|c|c|c|}
\hline \multicolumn{5}{|c|}{$\begin{array}{l}\text { TABLE-1 } \\
\text { PRELIMINARY in vitro ANTIBACTERIAL SCREENING } \\
\text { ACTIVITY OF ACID, HL AND COMPLEXES 1-4 }\end{array}$} \\
\hline \multirow[b]{2}{*}{ Complexes } & \multicolumn{4}{|c|}{ Inhibition zone $(\mathrm{mm})$} \\
\hline & $\begin{array}{l}\text { Bacillus } \\
\text { subtilis }\end{array}$ & $\begin{array}{c}\text { Escherichia } \\
\text { coli }\end{array}$ & $\begin{array}{l}\text { Pseudomonas } \\
\text { aeruginosa }\end{array}$ & $\begin{array}{l}\text { Staphy- } \\
\text { lococcus } \\
\text { aureus }\end{array}$ \\
\hline $\mathrm{HL}$ & - & - & - & - \\
\hline 1 & 8 & 8 & 9 & 8 \\
\hline 2 & 12 & 10 & 22 & 11 \\
\hline 3 & 13 & 11 & 19 & 12 \\
\hline 4 & 20 & 9 & 16 & 20 \\
\hline Chloramphenicol & 27 & 8 & 9 & 19 \\
\hline Doxycycline & 35 & 23 & 25 & 36 \\
\hline Rifampicin & 24 & 16 & 14 & 28 \\
\hline
\end{tabular}

Chloramphenicol, Doxycycline and Rifampicin

\section{Conclusion}

Complexes 1-4 have been successfully synthesized and their structures as well as the coordination number of tin(IV) atoms moieties have been characterized quantitatively and qualitatively. Based on the preliminary in vitro antibacterial screening activity, complex 4 [triphenyltin(IV)] showed better activity compared to complexes $\mathbf{1 - 3}$ [diorganotin(IV)] against Gram-positive bacterial strains but its activities are lower compared to the reference drugs.

\section{ACKNOWLEDGEMENTS}

The authors thank Malaysian Ministry of Higher Education, MOHE (Project No.: FRGS/1/2012/SG01/UTAR/02/1) and Universiti Tunku Abdul Rahman, UTAR (Project No.: IPSR/ RMC/UTARRF/C1-11/C07) for financial support as well as technical assistance and facilities.

\section{REFERENCES}

1. R. Zhang, J. Sun and C. Ma, J. Organomet. Chem., 690, 4366 (2005).

2. Y.F. Win, S.G. Teoh, J.B.-J. Teh, H.K. Fun and L. Zakaria, Acta Crystallogr., E63, m323 (2007).

3. M.M. Amini, A. Azadmehr, V. Alijani, H.R. Khavasi, T. Hajiashrafi and A.N. Kharat, Inorg. Chim. Acta, 362, 355 (2009).

4. S.M. Abbas, S. Ali, S.T. Hussain and S. Shahzadi, J. Coord. Chem., 66, 2217 (2013).

5. Y.F. Win, S.G. Teoh, M.R. Vikneswaran, J.H. Goh and H.K. Fun, Acta Crystallogr., E66, m695 (2010).

6. Y.-F. Win, C.-S. Choong, S.-T. Ha, C.K. Quah and H.K. Fun, Acta Crystallogr., E67, m535 (2011).

7. F.W. Yip, S.G. Teoh, B.M. Yamin and S.W. Ng, Acta Crystallogr., E66, m1164 (2010).

8. X. Xiao, D. Du, X. Han, J. Liang, M. Tian, D. Zhu and L. Xu, J. Organomet. Chem., 713, 143 (2012).

9. M. Gielen, M. Biesemans, D. de Vos and R. Willem, J. Inorg. Biochem., 79, 139 (2000).

10. K.A. Crouse, K.-B. Chew, M.T.H. Tarafder, A. Kasbollah, A.M. Ali, B.M. Yamin and H.K. Fun, Polyhedron, 23, 161 (2004).

11. M. Hanif, M. Hussain, S. Ali, M.H. Bhatti, M.S. Ahmed, B. Mirza and H.S. Evans, Turk. J. Chem., 31, 349 (2007).

12. S. Jabbar, I. Shahzadi, R. Rehman, H. Iqbal, Qurat-Ul-Ain, A. Jamil, R. Kousar, S. Ali, S. Shahzadi, M.A. Choudhary, M. Shahid, Q.M. Khan, S.K. Sharma and K. Qanungo, J. Coord. Chem., 65, 572 (2012).

13. F.T. Vieira, G.M. de Lima, J.R.S. Maia, N.L. Speziali, J.D. Ardisson, L. Rodrigues, A. Correa and O.B. Romero, Eur. J. Med. Chem., 45, 883 (2010)

14. O.D. Dhingra and J.B. Sinclair, Basic Plant Pathology Methods, CRC Press, United State, edn. 4, p. 245 (1987).

15. Y.-F. Win, C.-S. Choong, S.-G. Teoh, C.K. Quah and H.-K. Fun, Acta Crystallogr., E68, o488 (2012).

16. Y.-F. Win, C.-S. Choong, M.-H. Heng, C.K. Quah and H.-K. Fun, Acta Crystallogr., E67, m561 (2011).

17. G.K. Sandhu and S.P. Verma, Polyhedron, 6, 587 (1987).

18. L.L. Yeap and S.G. Teoh, J. Coord. Chem., 56, 701 (2003).

19. A. Sau and R.R. Holmes, J. Organomet. Chem., 217, 157 (1981).

20. M. Danish, H.G. Alt, A. Badshah, S. Ali, M. Mazhar and Nazar-ulIslam, J. Organomet. Chem., 486, 51 (1995).

21. J. Holecek, K. Handlír, M. Nadvornik and A. Lycka, J. Organomet. Chem., 241, 177 (1983); 258, 147 (1983).

22. J. Holecek, M. Nádvornik, K. Handlír and A. Lycka, J. Organomet. Chem., 315, 299 (1986). 